\title{
IKHTIAR GURU AGAMA DALAM MEMBINA KESEHATAN MENTAL GENERASI MUDA DI SMA IRSYADUL MUBTADIIN \\ GADING PROBOLINGGO
}

\author{
NANANG QOSIM \\ Institut Ilmu Keislaman Zainul Hasan
}

ABSTRACT

Educational institutions are faced with the rapid development of millennial times, so that the impact of the progress of the era has positive and negative impacts, the negative impact issues that concern the public include actions and deviant behavior from the community, such as immorality, gambling, robbery, consuming drugs, drinks hard and so on.

The deviant behavior is expected not to poison the young generation as the successor of the nation's life. The youth is the relay holder of the nation's future leadership, therefore the Irsyadul Mubtadiin High School educational institution strives as much as possible to educate and nurture the mental health of the young generation. Youth is a generation that is capable of achieving the nation's ideals to be proud of by all levels of society. Religious education taught by professional religious teachers is sought to be able to fortify the souls of the younger generation so that they are not affected by the current and negative effects of the changes and progress of the times.

Keyword: Religion Teacher, Mental Health, Young Generation 


\section{Pendahuluan}

\section{A. Hakikat Guru}

\section{Definisi Guru Agama}

Dalam KBBI definisi, Guru adalah seseorang yang profesinya atau pekerjaannya mengajar dan mendidik. ${ }^{1}$ Jadi kalau guru agama adalah seseorang yang profesinya mengajar pendidikan agama Islam.

H.M. Arifin, Guru agama adalah seorang hamba Allah yang mempunyai cita-cita Islami, yang telah matang rohaniah dan jasmaniah serta mamahami kebutuhan perkembangan siswa bagi kehidupan masa depannya. Ia tidak hanya mentransfer ilmu pengetahuan (transfer of knowledge), transfer nilai (Transfer of value), transfer budaya (transfer of culture) serta transfer keagamaan (transfer of religious) yang diperlukan oleh siswa akan tetapi juga tata aturan yang bersifat islami ke dalam pribadi siswa sehingga menyatu serta mewarnai prilaku mereka yang bernafaskan Islam. ${ }^{2}$

Menurut Athiyah Al-Abrosy mengatakan Guru adalah guru agama yang merupakan guru spiritual bagi seorang murid atau seorang bapak spiritual kepada anaknya dengan maksud memberikan santapan rohani berupa pelajaran ahklak dan budi pekerti yang luhur. ${ }^{3}$

Undang-Undang No. 14 Tahun 2005 tentang guru adalah pendidik professional dengan tugas utama mendidik, mengajar, membimbing, mengerahkan, melatih, menilai, dan mengevalusasi peserta didik pada pendidikan anak usia dini jalur pendidikan formal, pendidikan dasar, dan pendidikan menengah. ${ }^{4}$

Tugas guru agama berbeda dengan guru bidang studi lainnya, guru agama disamping melaksanakan tugas dan pembinaan bagi peserta didik ia juga membantu dalam pembentukan kepribadian dan mental anak didik tersebut sehingga anak didik tersebut dapat meningkatkan serta mengembangkan potensi keimanan dan ketaqwaan kepada Sang Pencipta. Oleh karena itu, guru agama masuk ke dalam kelas dengan apa yang ada sangat menunjang keberhasilan dalam melaksanakan tugas pendidikan agama bagi peserta didik; misalnya cara berpakaian, berbicara, bergaul, makan, minum, serta diamnya pun sangat mempunyai makna yang penting karena segala prilaku aktifitasnya diamati oleh lingkungan terutama tauladan bagi peserta didik. ${ }^{5}$

Firman Allah dalam surat An-Nahl ayat 125 :

\footnotetext{
${ }^{1}$ WJS Poerwodarminto, Kamus Umum Bahasa Indonesia, (Jakarta : Balai Pustaka, 2005), hlm. 870

${ }^{2}$ H.M Arifin, Ilmu Pendidikan Islam, Bumi Aksara, Jakarta, 1996, hal : 193

${ }^{3}$ Athiyah Al-Abrosy, Dasar-dasar Pokok Pendidikan Islam, Bulan Bintang, Jakarta, hal : 136

${ }^{4}$ Afnil Guza, Undang-undang SISDIKNAS dan Undang-undang Guru dan Dosen, (t.t.p: Asa Muda, 2009), hal. 52

${ }^{5}$ Zakiyah Darajat, Pendidikan Islam Dalam Keluarga, Ruhama. Jakarta, 1995, hal : 99
} 


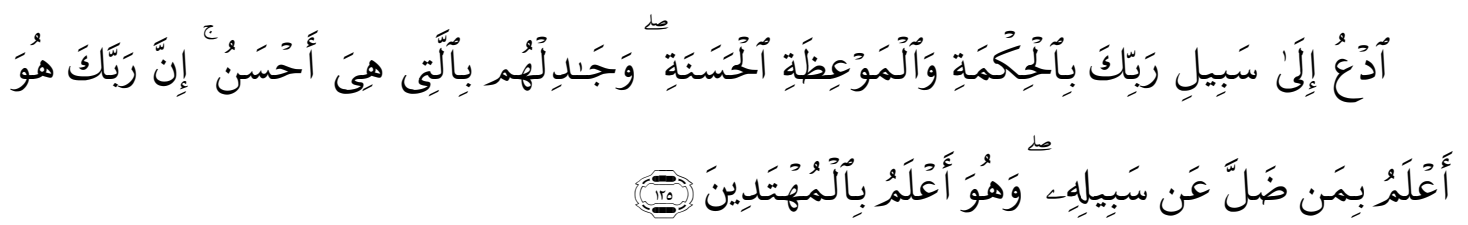

Artinya : 'Serulah (manusia) kepada jalan Tuhan-mu dengan hikmah' dan pelajaran yang baik dan bantahlah mereka dengan cara yang baik. Sesungguhnya Tuhanmu Dialah yang lebih mengetahui tentang siapa yang tersesat dari jalan-Nya dan Dialah yang lebih mengetahui orang-orang yang mendapat petunjuk. ${ }^{7}$

Ayat diatas bisa dipahami bahwa siapapun dapat menjadi pendidik agama Islam atau guru agama asalkan dia memiliki kualifikasi akademik, kemampuan (competency), pengetahuan (knowledge) serta mampu mengimplikasikan nilai (value) yang relevan yakni sebagai penganut agama yang patut diteladani dalam agama yang diajarkan dan bersedia menularkan pengetahuan agama serta nilainya kepada orang lain.

Pendidikan agama bukan hanya menyangkut masalah transformasi ajaran dan nilainya kepada pihak lain, akan tetapi lebih masalah yang sangat kompleks misalnya masalah peserta didik dengan berbagai macam latar belakangnya, sarana dan prasarana yang diperlukan untuk mencapai keberhasilan pendidikan agama, bagaimana metode atau pendekatan apa yang digunakan dalam pembelajaran, bagaimana mengorganisasikan dan mengelola isi pembelajaran agama tersebut serta seberapa jauh tingkat efektif dan efisiensi kegiatan tersebut serta usaha apa yang dilakukan untuk menimbulkan daya tarik siswa.

Upaya atau ikhtiar guru agama sangat kompleksitas, yang membutuhkan kajian secara mendalam, dalam kerangka kependidikan secara umum dapat dikatakan bahwa prilaku guru agama dipandang sebagai sumber pengaruh sedangkan tingkah laku siswa sebagai efek dari berbagai proses tingkah laku dari kegiatan interaksi dalam kehidupan sehari-hari.

\section{Tugas Guru Agama}

Tugas guru agama di sekolah sebagai berikut :

a) Guru agama sebagai pembimbing agama (spiritual) bagi peserta didik

Bertanggung jawab dan memberi kasih sayang serta keihklasan guru, dalam hal ini adalah guru agama mempunyai peran yang sangat penting bagi anak didik dalam mempelajari, mengkaji, mendidik dan membina mereka di kehidupannya, juga dalam mengantarkan menuntut ilmu untuk bekal kelak mengarungi samudra kehidupan yang akan mereka lalui, hendaknya seorang guru tidak segan-segan memberikan pengarahan kepada anak didiknya ketika bekal ilmu yang mereka dapatkan adalah untuk

\footnotetext{
${ }^{6}$ Hikmah: ialah Perkataan yang tegas dan benar yang dapat membedakan antara yang hak dengan yang bathil.

${ }^{7}$ Q.S. An-Nahal ayat: 125
} 
menjadikan mereka menjadi insan kamil, disamping itu juga seorang guru haruslah memberikan nasehat-nasehat kepada anak didiknya tentang nilai-nilai akhlak yang harus diamalkan dalam kehidupan sehari-hari. ${ }^{8}$

b) Guru Agama sebagai Sosok Teladan bagi peserta Didik

Sebagai teladan, guru harus memiliki kepribadian yang taat dijadikan profil dan idola, seluruh kehidupannya adalah figure yang paripurna. Karena itu kepribadian adalah masalah yang sangat sensitive sekali. Penyatuan kata dan perbuatan dituntut dari guru, bukan lain perkataan dengan perbuatan. Guru adalah mitra anak didik dalam kebaikan. Guru yang baik, anak didikpun menjadi baik. Tidak ada seorang guru yang bermaksud menjerumuskan anak didiknya kelembah kenistaan. ${ }^{9}$

c) Guru Agama sebagai orang tua kedua peserta didik

Dalam kegiatan proses belajar mengajar antara guru agama dan murid pada dewasa ini, kurang perhatian dan masih kelihatan ada pembatas, seorang guru sering tidak mampu tampil sebagai sosok figur yang pantas untuk diteladani dihadapan anak didiknya, apalagi mampu menjadi orang tua mereka, karena itu seringkali guru dipandang dan dinilai oleh muridnya tidak lebih sebagai orang lain yang bertugas menyampaikan materi pelajaran disekolah karena dibayar, kalau sudah menjadi demikian bagaimana mungkin seorang guru membawa, mengarahkan, menunjukkan dan membimbing anak didiknya menuju kepada pendewasaan diri sehingga menjadi manusia yang mandiri dan bertanggung jawab. ${ }^{10}$

d) Guru sebagai motivator bagi peserta didik

Seorang guru harus menciptakan kondisi belajar kondusif dan mendesain pembelajaran sedemikian rupa sehingga anak didik senang belajar, mengetahui tujuannya dan menyadari hakikat belajar, yakni sebagai bekal hidup. Oleh karena itu seorang guru haruslah selalu memberikan motivasi anak didiknya

e) Guru sebagai Fasilitator

Seorang guru berfungsi untuk memberikan kemudahan (kesempatan) kepada peserta didik untuk belajar. Guru hanya membantu memfasilitasi kegiatan pembelajaran bukan sebagai satu-satunya sumber belajar bagi peserta didik, namun guru berperan penting untuk dapat menunjukkan sumber-sumber belajar lain.

\section{Peranan Guru Agama dalam Membentuk Kepribadian Anak Didik.}

Guru tugasnya sebagai pendidik untuk membina kepribadian anak didiknya, seorang guru haruslah dapat membina kesabaran dirinya, terutama seorang guru agama haruslah sabar dan tabah ketika menghadapi berbagai macam ujian dan rintangan yang

\footnotetext{
${ }^{8}$ Abidin Ibnu Rusd, Pemikiran Al Ghozali Tentang Pendidikan, Pustaka Pelajar. Yogyakarata, 1991, hal : 75

${ }^{9}$ Syaiful Bahri Djamarah, Guru Dan Anak Didik Dalam Intreraksi Edukatif, (Jakarta: Rineka Cipta, 2000), hal. 41

${ }^{10}$ Abidin Ibnu Rusd, op cit, hal : 67
} 
menghalangi, guru haruslah dapat memberikan solusi yang terbaik ketika anak didiknya sedang menghadapi masalah, tidak boleh memutuskan hukuman ketika waktu marah terutama masalah yang berhubungan langsung dengan proses belajar mengajar. ${ }^{11}$

Supaya mampu melaksanakan tugasnya dalam membina kepribadian anak didik maka kepada semua guru agama tanpa memandang tingkat dan jenis sekolah yang dihadapinya, dituntut memiliki perangkat kompetensi kepribadian meliputi :

a) Mengembangkan dan mengaplikasikan sifat-sifat terpuji, adapun sifat-sifat terpuji yang harus dimiliki oleh seorang guru :

1. Ikhlas dalam pekerjaan, seorang guru dalam mendidik dan membina anak didiknya harus mempunyai rasa tulus ikhlas.

2. Pemaaf, seorang guru dalam medidik dan membina anak didiknya harus senantiasa pemaaf, karena mungkin dalam kegiatan tersebut ada anak didik yang menjengkelkan, maka guru harus bisa memahami hal tersebut.

3. Sabar, seorang guru dalam mendidik dan membina anak didiknya harus disertai rasa sabar, karena menghadapi berbagai macam karakter anak

4. Zuhud, seorang guru agama tidak boleh mengutamakan materi, mengajar hanya untuk mencapai ridho Allah semata, bukan mencari upah, gaji atau balas jasa. ${ }^{12}$

b) Mengembangkan dan mengaplikasikan Iman dan Taqwa

Dalam membentuk pribadi yang Islami haruslah atas dasar kesadaran penyerahan diri kepada Allah, hal ini menyangkut aqidah dengan cara beriman kepada ke-Esaan Allah dan menyangkut Ahklak yang berarti seseorang harus berakhlak seperti yang telah diprintahkan oleh Allah melalui Rasul-Nya. ${ }^{13}$

c) Mengembangkan dan mengaplikasikan jiwa kemasyarakatan

d) Mengembangkan sikap pelayanan terhadap anak didik

\section{B. Generasi Muda}

\section{Definisi Generasi Muda}

Kata "generasi" adalah sekalian orang yang kira-kira sama waktu hidupnya; angkatan; turunan; masa orang-orang satu angkatan hidup: sedangkan "muda" adalah kelompok (golongan, kaum) muda; ${ }^{14}$

Menurut WHO Pengertian pemuda adalah seseorang yang berusia 10 sampai 24 tahun (young people), sedangkan untuk usia 10 sampai 19 tahun disebut WHO menyebutnya dengan adolescenea/ remaja.

\footnotetext{
${ }^{11}$ Zakiyah Darajat, Pendidikan Agama dalam Pembinaan Mental, Bulan Bintang, Jakarata,1968, hal:127

${ }^{12}$ Athiyah Al-Abrosy, op cit, hal : 137-138

${ }^{13}$ M. Jamaluddin Mahfud, PsikologiAnak dan Remaja Muslim, Pustaka Al-Kautsar, Jakarata, 2001, hal:113

${ }^{14}$ https://kbbi.web.id/generasi. di akses tgl 30 Nopember 2018
} 
Mulyana (2011) Definisi pemuda adalah individu yang memiliki karakter dinamis, artinya bisa memiliki karakter yang bergejolak, optimis, dan belum mampu mengendalikan emosi yang stabil.

Banyak persepsi mengenai generasi muda sampai sekarang ini belum ada kesepakatan para ahli, namun pada dasarnya ada kesamaan mengenai pengertian generasi muda tersebut, yaitu beralihnya seseorang dari masa kanak-kanak menuju masa remaja atau muda dengan disertai perkembangan fisik, psikis dan non fisik (jasmani, emosi, pola pikirannya dan sebagainya).

Tidak mudah kita gambarkan membangun generasi muda sebagai penerus bangsa ini, namun kita harus optimis bahwa yang kita persiapkan nantinya akan dapat mencapai hasil yang maksimal, masa muda yang penuh kesenangan dan diwarnai senda gurau, akan tetapi hal itu tidak dapat dibiarkan begitu saja karena bila tidak ada control yang jelas maka dampaknya mungkin kurang baik, untuk itu alangkah baiknya pada masa tersebut dimasukkkan nilai-nilai agama yang dapat membantu serta mendorong generasi agar bisa memberikan yang terbaik kepada keluarga, sekolah ,lingkungan masyarakat bangsa dan Negara.

\section{Ciri-Ciri Generasi Muda}

Ciri-ciri yang dimiliki generasi muda antara lain adalah :

a. Ciri-ciri yang menonjol dari generasi muda, antara lain :

- Keberanian dan keterbukaan dalam menyerap nilai-nilai dan gagasan baru.

- Sikap dan tindakannya dengan kenyataan yang ada saat dialaminya waktu itu.

- Kemurnian idealisme.

- Berkeinginan segera mewujudkan gagasan-gagasan dan sedikitnya pengalamanpengalaman yang dapat merelevansikan pendapat. ${ }^{15}$

b. Di tinjau dari sudut kepribadiannya, maka generasi muda yang identik dengan sebutan remaja ini mempunyai beberapa ciri tertentu, baik secara lahir ataupun secara batin, adapun beberapa ciri-ciri tersebut antara lain :

- Keinginan yang kuat untuk mendapatkan kepercayaan dari kalangan dewasa, walaupun mengenai masalah tanggung jawab secara relatife belum matang.

- Perkembangan fisik yang pesat;

- Keinginan yang kuat untuk mengadakan interaksi sosial dengan kalangan yang lebih dewasa atau yang dianggap lebih matang pribadinya;

- Adanya perkembangan taraf intelektual ( dalam arti netral ) untuk mendapatkan identitas diri.

${ }^{15}$ Noer Hanie Khukmiati, Pola Perkekmbangan Pendidikan Agama Islam Guna Membina Generasi Muda, MPA, 15 Maret 1999 
- Menginginkan sistem kaidah dan nilai yang sesuai dengan kebutuhan atau keinginannya, ${ }^{17}$

c. Menurut psikologi perkembangan bahwa ciri-ciri remaja adalah terjadinya pertumbuhan fisik, perkembangan seksual, cara berfikir kausalitas atau sebab akibat, emosi yang meluap-luap, mulai tertarik dengan lawan jenisnya, menarik perhatian lingkungan dan terikat dengan kelompok. ${ }^{18}$

d. Menurut James E. Garder usia remaja dapat menjadi suatu masa yang membingungkan, tubuh remaja mengalami perubahan dalam cara yang menakjubkan dan luar biasa. ${ }^{19}$

e. Menurut psikologi agama adalah pertumbuhan pikiran dan mental, perkembangan perasaan, pertimbangan sosial, perkembangan moral, sikap dan minat, serta mungkin sebagai tambahan adalah masa timbulnya konflik, terutama pertentangan terhadap agama yang selama ini mereka anut. ${ }^{20}$

\section{Lingkungan Generasi Muda}

Generasi muda yang termasuk sebagai makluk sosial yang tidak dapat hidup sendiri dan juga memerlukan bantuan orang lain, pasti akan menjalin kerjasama dengan orang lain atau lingkungan di luar dirinya, misalnya lingkungan keluarga, yakni orang tua, saudara, kerabat serumah atau yang jauh, dan juga lingkungan masyarakat disekitarnya.

Lingkungan generasi muda menurut Tri Pusat Pendidikan, yaitu ${ }^{21}$ :

a. Lingkungan Keluarga

Peran serta orang tua dalam keluarga tidak dapat diwakilkan, karena orang tualah yang kelak menjadikan anak-anaknya sesuai apa yang mereka harapkan, orang tua seharusnya memberikan pendidikan serta menanamkan nilai-nilai agama kepada anak-anaknya meliputi pendidikan aqidah, ibadah, dan akhlak. Pendidikan agama harus diberikan sejak dini sebelum mereka terpengaruh oleh pendidikan orang lain.

b. Lingkungan Sekolah

Sekolah sebagai lingkungan yang plural, terdiri dari anak didik yang beraneka ragam watak dan karakternya, di tempat inilah mereka bergaul dan bermain yang menyebabkan bertambahnya wawasan pengalaman dari si anak, pergaulan dengan sesama teman tidak selalu membawa kebaikan apabila berbuat

\footnotetext{
${ }^{17}$ Soerjono Soekanto, Psikologi Keluarga, Rineka Cipta, Cet. Ke-2, 1992, hal : 51-52

${ }^{18}$ Zulkifi, PsikologiPerkembangan, Rosda Karya, Bandung, Cet. Ke-6, 1980, hal : 65-67

${ }^{19}$ James E.Gardner, Memaham iGejolak Remaja, P.T Mitra Utama, Jakarta, 1985, hal : 51-52

${ }^{20}$ Jalaluddin, Filsafat Pendidikan Islam, P.T Raja Grafindo Persada, Jakarta, Cet. Ke-2, 1997, hal :72

${ }^{21}$ Rangkuman Tri Pusat Pendidikan. [Online]. Tersedia: diakses tanggal 30 Oktober 2018
} 
seenaknya, dalam arti ia bergaul dalam rangka mengisi kekosongan waktu untuk bermain, bukan semata untuk belajar atau yang lainnya.

c. Lingkungan Masyarakat

Masyarakat merupakan bagian dari suatu Negara, dan generasi muda termasuk bagian dari masyarakat, dari lingkungan masyarakat inilah biasanya terjadi permasalahan yang lebih kompleks dari sekolah atau keluarga, mau atau tidak mau generasi muda harus masuk dalam lingkungan masyarakat, otomatis harus mengikuti aturan dan norma yang ada di masyarakat tersebut.

\section{Permasalahan Generasi Muda}

Para pemuda dalam proses pencarian jati dirinya, masa penuh problematika, juga dikatakan masa remaja adalah masa yang paling indah dan penuh kenang-kenangan yang tak terlupakan, masa transisi dan peralihan perlu adanya bimbingan dari siapapun, baik dari orang tua atau orang yang lebih dewasa darinya sehingga mereka dapat lebih terarah dalam menjalani hidup ini.

Generasi muda sekarang ini dalam upaya peningkatan kualitas dari bakat maupun minatnya serta rasa toleransi terhadap permasalahan sosial yang muncul di tengah-tengah masyarakat. Bangsa kita telah terbebas dari penjajahan tetapi sekarang ini bangsa kita dihadapkan pada penjajahan baru, yaitu korupsi, kolusi, nepotisme, pergaulan bebas remaja, asusila, narkoba dan sebagainya, yang menghancurkan generasi muda..

\section{Kesehatan Mental}

\section{Pengertian Pembinaan Kesehatan Mental}

Dalam kamus besar bahasa Indonesia, Departemen Pendidikan dan kebudayaan sebelum berubah menjadi DIKNAS, memberikan pengertian kata "pembinaan" dalam kamus tersebut sebagai sebuah proses, perbuatan, cara, membina, pembaharuan ; penyempurnaan atau arti secara luasnya adalah usaha, tindakan, dan kegiatan yang dilakukan secara berdaya guna dan berhasil untuk memperoleh hasil yang baik. ${ }^{22}$

Menurut etimologi "mental" berasal dari kata latin, yaitu mens atau mentis yang berarti jiwa, nyawa, sukma, ruh, dan semnagat.1) Kesehatan mental merupakan ahli bahasa dari mental Hygiene atau Mental Health berasal dari kata Hygiene dan Mental. Secara etimologi Hygiene dari kata Hygea yaitu nama dewi kesehatan Yunani kuno yang mempunyai tugas mengurus masalah kesehatan manusia di dunia. ${ }^{23}$

Pendapat Pieper dan Uden kesehatan mental adalah suatu keadaan dimana seseorang tidak mengalami perasaan bersalah terhadap dirinya sendiri, memiliki estimasi

\footnotetext{
${ }^{22}$ Depdikbud, Kamus Besar Bahasa Indonesia, Balai Pustaka, Jakarta, 1990, hal : 117

${ }^{23}$ Syamsu Yusuf, Mental Hygiene Pengembanagan Kesehatan Mental dalam Kajian Psikologi dan Agama,

(Bandung: Pustaka Bani Quraisy, 2004). h. 7.
} 
yang relistis terhadap dirinya sendiri dan dapat menerima kekurangan atau kelemahannya, kemampuan menghadapi masalahmasalah dalam hidupnya, memiliki kepuasan dalam kehidupan sosialnya, serta memiliki kebahagiaan dalam hidupnya. ${ }^{24}$

\section{Tujuan Pembinaan Kesehatan Mental}

a. Meningkatkan Keagamaan (Keimanan)

Dalam ajaran agama bisa ditemukan bahwa iman sesorang dapat bertambah dan berkurang. Disaat iman bertambah maka dapat terlihat dalam gejala prilaku religiusnya, sebaliknya, apalagi kondisi mental keimanan remaja masih dalam kondisi pembinaan, karena keimanan yang mungkin dimiliki remaja sangatlah labil, sehingga mudah terpengaruh oleh faktor luar. Perlu pembinaan yang inklusif dan intensif.

b. Memperkokoh Kondisi Psikis dan Fisik

Keseimbangan kondisi psiksis dan fisik akan menyebabkan adanya kemungkinan yang nyata dalam diri generasi muda yang ditandai dengan kesanggupan menyesuaikan terhadap dunianya sendiri, lingkungan keluarga dan sosialnya. Atau menentukan sifat seperti, seseorang menerimanya beserta kesanggupan menciptakan hubungan sosial yang baik.

c. Memperkokoh Peran di Masyarakat.

Dalam kehidupan bermasyarakat, yaitu bergerak secara dinamis menuju kearah yang dianggap lebih mandiri dan sempurna, Memang terhadap cepatnya laju perubahan tersebut maka semakin majunya manusia berfikir dalam berbagai macam ilmu pengetahuan dan semakin majunya budaya manusia sebagai hasil karya, cipta, rasa dan karsa manusia dalam kehidupan yang dinamis tersebut.

\section{Strategi Pembinaan Mental Generasi Muda}

Pembentukan kepribadian yang Islami, ada beberapa strategi yang harus ditempuh di sekolah, antara lain

a) Tindakan Prefentif / Pencegahan

1. Pendidikan aqidah atau tauhid atau ke Tuhanan

Memberikan Pendidikan tauhid atau aqidah sebagai landasan hidup harus diberikan kepada generasi muda sedini mungkin, karena bila tauhid atau dengan kata lain iman telah tertanam dengan kuat dalam dirinya maka ia tidak akan mudah tergoda oleh arus negatif dari perkembangan zaman.

2. Pemantapan Tentang Ibadah

Melakukan Ibadah merupakan bukti nyata dari keimanan kepada Allah SWT, dan tanda dari penyerahan diri kepada-Nya, orang yang menjadikan ibadahnya sebagai aktifitas pengisi waktunya maka kehidupannya akan

\footnotetext{
${ }^{24}$ Pieper, J \& Uden, M.V. (2006). Religion in Coping and Mental Health Care. New York: Yord Universuty Press,
} Inc. 
tentram dan damai dalam kondisi apapun, karena ia menyerahkan diri sepenuhnya kepada Allah semata, dengan menjalankan apa yang menjadi perintah Allah dan menjauhi segala yang menjadi larangan-Nya.. ${ }^{25}$

3. Menanamkan Pendidikan Akhlakul Karimah

Pendidikan yang diberikan harus dilakukan dengan metode kesuritauladanan dan pembiasaan. Pendidik terutama orang tua harus menerapkan metode tersebut sebelum diberikannya kepada si anak, karena banyak orang orang berceramah akan tetapi mereka sendiri tidak dapat melaksanakannya. $^{26}$

Firman Allah surat Ass Shaff ayat 3 :

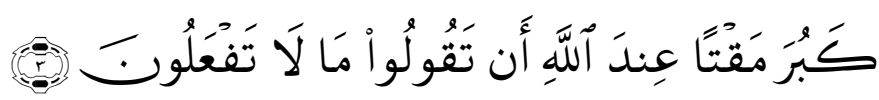

Artinya : 'Amat besar kebencian di sisi Allah bahwa kamu mengatakan apaapa yang tiada kamu kerjakan'.

Cara melaksanakan pembinaan dan pendidikan akhlak yang pertama harus dalam keluarga, yaitu dengan memberikan bimbingan akhlak kepada mereka terutama generasi muda antara lain :

a. Mengarahkan agar selalu mengerjakan ibadah, karena ibadah itu dapat menentramkan hati, juga bisa mengarahkan prilaku manusia untuk dapat berbuat baik.

b. Mengarahkan agar selalu rajin mengikuti pengajian-pengajian atau majelis ilmu, terutama mengenai ilmu agama.

c. Menciptakan suasana akrab dan kasih sayang terhadap sesama teman dan dengan yang lainnya.

d. Selalu mengontrol buku-buku pelajaran dan buku-buku bacaanya, jangan sampai mereka membaca buku-buku yang bersifat negative, misalnya buku porno, buku yang berisikan kekerasan dan kenakalan remaja.

e. Tidak terlalu memberikan kebebasan padanya, karena jika terlalu bebas di khawatirkan salah jalan dan salah pergaulan. ${ }^{27}$

\section{b) Tindakan Represif / Menindak}

Arti tindakan represif yaitu usaha atau tindakan untuk menindak dan menahan kenakalan remaja, mungkin juga dengan cara menghalangi peristiwa yang lebih parah. Cara ini berbeda dengan cara preventif, adapun cara yang baik adalah dengan memberikan hukuman/sanksi yang bersifat pelajaran dan mendidik artinya hukuman akan menjadikan suatu pelajaran agar mereka yang berbuat salah dapat sadar dari

\footnotetext{
${ }^{25}$ Hasan Basri, Remaja Berkualitas, Pustaka Pelajar, Jakarta, 1995, hal : 15

${ }^{26}$ Daud Rosyid, Islam dalam Berbagai Dimensi, GIP, Jakarta, 1998, hal : 47

${ }^{27}$ Mahjuddin, Membina Akhlak Anak, Al-Ikhlas, Surabaya, 1995, hal : 75-76
} 
kesalahan tersebut dan diarahkan kepada tujuan yang bermanfaat. Sebaliknya, ketika ada seorang anak berubah lebih baik maka kita harus memberi apresiasi atau penghargaan/reward.

\section{Upaya Guru Agama dalam Membina Mental Generasi Muda}

upaya guru agama tersebut dalam membina mental generasi muda antara lain:

1. Memberikan pembinaan kepada generasi muda dengan arah yang jelas, berarti sudah ada pedoman yang akan dilaksanakan, antara lain sebagai berikut :

a. Orientasi kepada Tuhan Yang Maha Esa, nilai-nilai kerohanian yang luhur dan falsafah hidup Pancasila.

b. Orientasi ke dalam terhadap dirinya sendiri.

c. Orientasi ke luar terhadap lingkungan ( sosial, budaya, dan alam ) dan masa depan.

2. Memberikan pembinaan kepada generasi muda tujuan yang jelas, berarti ada kepastian target yang hendak dicapai, tujuan tersebut.

Tujuan pembinaan generasi muda sebagaimana pendapat di atas merupakan tujuan secara umum, sedangkan menurut ajaran Islam antara lain :

1. Kekokohan aqidah dan kedalaman spiritual keagamaan

2. Keagungan akhlak/moral

3. Keluasan ilmu/intelektual

4. kematangan profesional. ${ }^{28}$

Upaya pemerintah yang berusaha mengembangkan iklim yang kondusif bagi generasi muda dalam mengaktualisasikan segenap potensi, bakat dan minat dengan memberikan kesempatan serta keleluasaan mengorganisasikan dirinya secara bebas dan merdeka sebagai wahana untuk menjadi pemimpin bangsa yang beriman, bertaqwa, berakhlak mulia, demokratis, mandiri serta tanggap terhadap perkembangan sosial.

${ }^{28}$ Buku pedoman PKLI STAIN Malang, Penerbit LP3M STAIN Malang, 2000, hal : 1 


\section{A. Kesimpulan}

Kegiatan pembinaan mental generasi muda yang dilakukan oleh guru agama SMA Irsyadul Mubtadiin telah mengadakan program kegiatan keagamaan yang dibina secara intensif dan inklusif oleh guru agama dan jajaran Sekolah sehingga tercipta generasi berkarakter, agamis, ilmiah, berakhlakul karimah dan intelektualitas tinggi.

\section{B. Saran-saran}

Upaya guru agama dalam membina mental generasi muda agar dapat membentengi diri dari hal-hal yang negatif, maka sebaiknya orang tua juga diberikan pengarahan untuk turut serta membantu dan memberikan motivasi kepada anak-anaknya untuk aktif mengikuti pelajaran agama serta kegiatan keagamaan seperti Istighosah, Sholawatan dan Maulidan yang ada di sekolah.

Mungkin tulisan ini masih jauh dari kesempurnaan, mohon bantuannya bagi pembaca yang budiman untuk memberikan saran dan kritik yang membangun. 


\section{DAFTAR PUSTAKA}

WJS Poerwodarminto, Kamus Umum Bahasa Indonesia, (Jakarta : Balai Pustaka, 2005), hlm. 870

H.M Arifin, Ilmu Pendidikan Islam, Bumi Aksara, Jakarta, 1996, hal : 193

Athiyah Al-Abrosy, Dasar-dasar Pokok Pendidikan Islam, Bulan Bintang, Jakarta, hal : 136

Afnil Guza, Undang-undang SISDIKNAS dan Undang-undang Guru dan Dosen, (t.t.p: AsaMuda, 2009), hal. 52Zakiyah Darajat, Pendidikan Islam Dalam Keluarga, Ruhama. Jakarta, 1995, hal : 99

Abidin Ibnu Rusd, Pemikiran Al Ghozali Tentang Pendidikan, Pustaka Pelajar. Yogyakarata, 1991 , hal : 75

Syaiful Bahri Djamarah, Guru Dan Anak Didik Dalam Intreraksi Edukatif, (Jakarta: Rineka Cipta, 2000), hal. 41

Zakiyah Darajat, Pendidikan Agama dalam Pembinaan Mental, Bulan Bintang, Jakarata,1968, hal: 127

M. Jamaluddin Mahfud, PsikologiAnak dan Remaja Muslim, Pustaka Al-Kautsar, Jakarata, 2001, hal:113

Noer Hanie Khukmiati, Pola Perkekmbangan Pendidikan Agama Islam Guna Membina Generasi Muda, MPA, 15 Maret 1999

Soerjono Soekanto, Psikologi Keluarga, Rineka Cipta, Cet. Ke-2, 1992, hal : 51-52

Zulkifi, PsikologiPerkembangan, Rosda Karya, Bandung, Cet. Ke-6, 1980, hal : 65-67

James E.Gardner, Memaham iGejolak Remaja, P.T Mitra Utama, Jakarta, 1985, hal : 51-52

Jalaluddin, Filsafat Pendidikan Islam, P.T Raja Grafindo Persada, Jakarta, Cet. Ke-2, 1997, hal $: 72$

Depdikbud, Kamus Besar Bahasa Indonesia, Balai Pustaka, Jakarta, 1990, hal : 117

Syamsu Yusuf, Mental Hygiene Pengembanagan Kesehatan Mental dalam Kajian Psikologi dan Agama, (Bandung: Pustaka Bani Quraisy, 2004). h. 7.

Pieper, J \& Uden, M.V. (2006). Religion in Coping and Mental Health Care. New York: Yord Universuty Press, Inc.

Hasan Basri, Remaja Berkualitas, Pustaka Pelajar, Jakarta, 1995, hal : 15

Daud Rosyid, Islam dalam Berbagai Dimensi, GIP, Jakarta, 1998, hal : 47

Mahjuddin, Membina Akhlak Anak, Al-Ikhlas, Surabaya, 1995, hal : 75-76 